J. Clin. Chem. Clin. Biochem.

Vol. 21, 1983, pp. 683-693

\title{
A Multi-centre Evaluation of the FP-900 Analyzing System
}

By Nils-Erik Saris

University of Helsinki, Department of Medical Chemistry, Helsinki, Finland

Maarit Kansanen

Labsystems Oy, Research Laboratories Helsinki, Finland

Riitta Hekali

Helsinki University Central Hospital, Surgical Hospital, Helsinki, Finland

Liisa Huurrekorpi

University of Helsinki, Department of Medical Chemistry, Helsinki, Finland

Helena Kivistö

Institute of Occupational Health, Helsinki, Finland and

Toini Lahikainen

Koskela Hospital, Helsinki, Finland

(Received January 7/May 20, 1983)

Summary: The performance of the FP-900 Analyzing system manufactured by Labsystems Oy, Helsinki, Finland, was evaluated in a multi-centre study according to the principle outlined in the 1st Draft of the Standard for Instrument Testing produced by the European Committee for Clinical Laboratory Standards (ECCLS). The FP-900 System comprises a photometer for simultaneous measurement of the absorbance in a nìne-compartment cuvette block, and the accessories for handling samples (sampler, simultaneous dispensing of 9 reagent charges, incubator with thermostat and shaker, and centrifuge); the photometer function, printout of results and data processing are programmable with a microprocessor. The performance specifications given by the manufacturer were checked when appropriate. As examples of typical methodologies cholesterol was selected as an end-point absorbance method, creatinine as a fixed-time (two-point) kinetic and aspartate aminotransferase as multi-point, continuous method. The within- and between-laboratory imprecision, deviation from assigned values of commercial control sera, and carry-over were determined. The performance was compared with other analytical systems: Mark I Autoanalyżer and Hitachi 705. The cost, speed and capacity was estimated from the results of the present study. The performance of the analyser and results of applying the ECCLS Draft to actual instrument testing are discussed.

\section{Multizentrische Prüfung des FP-900 Analyse-Systems}

Zusammenfassung: Das Analysensystem FP 900, hergestellt von Labsystems Oy, Helsinki, Finnland, wurde nach den Richtlinien zur Prüfung von Geräten der Europäischen Kommission für Standards in der Klinischen Chemie (ECCLS) in einer multizentrischen Studie geprüft. Das Instrument besteht aus einem Photometer mit 
gleichzeitiger Messung der Absorption in den neun Kuvetten des Kuvettenblockes samt Zusatzgeräte für Pipettieren (9 auf einmal), Thermostat und Rührer, und Zentrifuge. Die Funktionen des Photometers, Datenverarbeitung und das Ausschreiben werden mit einem Mikroprozessor programmiert.

Die Spezifikationen der Hersteller wurden überprüft. Verschiedene Bestimmungen wurden verglichen in den beteiligten Laboratorien: Cholesterin als Absorbanz-Endpunkt Methode, Kreatinin als Zwei-Punkt-Meßmethode und Aspartataminotransferase als eine kontinuierliche Methode. Die Variation (Imṕrecision) der Ergebnisse innerhalb und zwischen den Laboratorien, die Abweichung von den Sollwerten der kommerziellen Kontrollseren sowie Verschleppung wurden ermittelt. Die Analysenergebnisse wurden verglichen mit den Daten von anderen Geräten: Mark I Autoanalyzer und Hitachi 705. Die Kosten, Geschwindigkeit und Kapazität wurden aus den Ergebnissen der Studie geschätzt. Die Erfahrungen mit dem Gerät und den Richtlinien zur Geräteprüfung nach ECCLS werden diskutiert.

\section{Description of the Analytical System}

The FP-900 Analyzing system from Labsystems Oy (Helsinki, Finland) has been developed from the FP9 System, which has been in use for several years. It consists of the following modules: manual multichannel pipettes or an automatic sampler for sample preparation, a thermostated incubator and programmable multichannel photometer. The set of three continuously adjustable nine-channel Finnpipettes covers the volume range of 5-1000 $\mu$ l. They are designed to transfer nine equal volumes of liquid simultaneously. The FP-801 sampler is an automatic microprocessor-controlled sample preparation unit acting both as a dispenser and as a dilutor. The FP801 operates with one dispensing needle connected to a standard Hamilton syringe $(1-100 \mu \mathrm{l})$ measuring the sample volume and to a peristaltic pump measuring the reagent volume $(50-1000 \mu \mathrm{l})$. The sample tubes and cuvettes are carried in special trays with a maximum capacity of 36 samples. The tip is washed in a special washing assembly before each subsequent sample to minimize carry-over. The photometer has nine optical light beams passing vertically through the nine-cuvette-block assembly. The disposable cuvettes have flat, optical quality windows in the bottom. The measuring volume in a cuvette can be varied from 300-900 $\mu$ l. The theoretical and practical consequences of the arrangement of the vertical measuring system have been discussed elsewhere $(1,2)$.

The FP-901 Analyzer is microprocessor-controlled and preprogrammed for a number of common procedures in clinical chemistry. The parameters of the tests are entered by the user and can be stored in the memory of the instrument for up to 34 tests. Six different programs are available:

1. an absorbance print-out;

2. a factor program;

3. an end-point program;
4. a two-point program with standard or factor mode;

5. a two-point kinetic program, and

6. an continuous enzyme measuring program.

The thermostat unit permits incubation of samples at $25^{\circ} \mathrm{C}, 30^{\circ} \mathrm{C}$ or $37^{\circ} \mathrm{C}$. The maximum capacity of the unit is 54 samples. It is also equipped with a mixer and with space for keeping reagents at the desired temperature.

A centrifuge with rotors designed for nine-place test tube blocks as well as for ordinary test tubes is also available.

All modules of the FP-900 Analyzing system can be operated independently, which increases the capacity and makes the system flexible. All units are bench top types occupying an area of about $0.5 \mathrm{~m}^{2}$, when one of each is used.

The manufacturer gives the following performance specifications for the photometer: linear range $0.0-$ 2.0 A with a maximum deviation of $0.5 \%$; noise $0.001 \mathrm{~A}$ at 0.0 absorbance; drift $0.003 \mathrm{~A} / \mathrm{h}$; resolution $0.001 \mathrm{~A}$; photometric inaccuracy including interchannel variation $1.0 \%$; wavelength accuracy $\pm 2.0 \mathrm{~nm}$; half-band width $4-6 \mathrm{~nm}$ in the UV-range and $8-12 \mathrm{~nm}$ in the visible range; cuvette cross sectional area $0.760 \pm 0.002 \mathrm{~cm}^{2}$, liquid volume $300-$ $1000 \mu \mathrm{l}$; measurement time for 9 samples $<2 \mathrm{~s}$. Temperature accuracy for the thermostat. unit $\pm 0.1^{\circ} \mathrm{C}$ measured in the sample.

\section{Outline of the Evaluation Protocol}

Four clinical laboratories and the research and development laboratory of the manufacturer, all situated in Helsinki, participated the evaluation study.

All laboratories were familiar with the operational technique having the experience of one to five years on the FP-9/FP-900 Analyzing, system. However, 
the automatic sampler unit, the FP-801, was delivered to the laboratories just before the start of the evaluation.

Three methods, cholesterol, creatinine and aspartate aminotransferase, were selected to represent different types of methodologies: end-point, fixed time (= two-point) and continuous (= multi-point) respectively. However, each laboratory took part only in those methods which were part of their daily routine work. The participating laboratories and the abbreviations used in this text are listed below:

LAB 1: University of Helsinki, Department of Medical Chemistry, Helsinki.

LAB 2: Institute of Occupational Health, Laboratory of Biochemistry, Helsinki.

LAB 3: Koskela Hospital, Central Laboratory, Helsinki.

LAB 4: Helsinki University Central Hospital, Surgical Hospital,Clinical Laboratory,Helsinki.

LAB 5: Labsystems Oy, Research Laboratories, Helsinki.

The evaluation was planned to conform to the ECCLS' 1st Draft Standard for Instrument Testing (3) including a familiarisation period, a short term trial, a long term trial and a comparison of analytical systems. The evaluation was started simultaneously in all laboratories in March 1982. During the familiarisation period of about one week the laboratory personnel were trained by the manufacturer to use the new units of the analyser system, specially the sampler unit. The comparability of the participating laboratories and the correct technical performance of the instruments was confirmed by a short term trial. During this trial three different control sera were analysed for ten days. When evaluating the results some slight changes in assay performance were agreed by the participants in order to make the performance of the procedures identical in all laboratories. One of the sampler units was readjusted by the mannufacturer.

All criteria for continuing the evaluation study confirmed in the ECCLS' Draft were met and the main part of the work, the long-term trial, was started in May 1982. Five different control sera, containing the constituents with low, normal or high concentrations, were analysed for 11-15 days during a period of 3-4 weeks.

Finally, in the correlation study the FP-900 Analyzing system was compared with the Technicon Autoanalyzer (creatinine determination) and with the $\mathrm{Hi}$ tachi 705 (aspartate aminotransferase and cholesterol determinations), using routine patients' sera.

\section{Materials and Methods}

Apparatus

FP-901 Analyzer, FP-801 Sampler, FP-400 Incubator, and ninechannel Finnpipettes 50-200 $\mu \mathrm{l}$ and $200-1000 \mu \mathrm{l}$ from Labsystems Oy, (Pulttitie 9-11, SF-00810 Helsinki 81, Finland).

Mark I Autoanalyzer from Technicon Instruments Corporation (Tarrytown, NY 10591, U.S.A.).

Hitachi 705 from Hitachi Ltd. (Tokyo, Japan).

\section{Reagents and procedures}

Determination of aspartate aminotransferase ${ }^{1}$ )

For the FP-901, the ASAT/AST/GOT-reagent kit, cat. No. 191337, was obtained from Boehringer Mannheim GmbH (D-6800 Mannheim 31, F.R.G.) and for the Hitachi 705 ASAT-I and ASAT/ALAT-II-reagents were obtained from Oy Medix Ab (P.B. 819, SF-00101 Helsinki 10, Finland). The assay conditions were according to the recommendations of Scandinavian Society for Clinical Chemistry and Clinical Physiology (4).

FP-901 procedure: $90 \mu \mathrm{l}$ of serum and $600 \mu \mathrm{l}$ of reagent were dispensed using the FP-801 sampler. After the preincubation period of 10 minutes at $37^{\circ} \mathrm{C}, 60 \mu \mathrm{l}$ of the starter reagent were added with the nine-channel Finnpipette. The measurement was started after a lag time of 60 seconds and the reaction was followed for 90 seconds. The analyser measures nine absorbance values during the reaction time, fits a regression line through the measured points and checks the linearity according to the preset error limits.

For the Hitachi 705 the procedure recommended by the manufacturer was used.

\section{Determination of cholesterol}

For the FP-901 and for the Hitachi 705, Cholesterol CHODPAP, High Performance reagent kit, cat. No. 237574, was obtained from Boehringer Mannheim.

For the calibration of the FP-901 two standard solutions containing $5.0 \mathrm{mmol} / \mathrm{h}$ and $7.5 \mathrm{mmol} / \mathrm{h}$ of cholesterol, No. 531 and No. 532 (Lääketehdas Orion, P.B. 8, SF-02101 Espoo 10, Finland) were used. The Hitachi 705 was calibrated with the ais of Precinorm U, cat. No. 171743 (Boehringer Mannheim).

FP-901 procedure end-point: $10 \mu$ of serum or standard and 500 $\mu \mathrm{l}$ of cholesterol reagent were dispensed with the FP-801 sampler. The measurement was performed after 30 minutes incubation at room temperature. The calibration was made with two standard solutions measured in triplicate for every assay series.

For the Hitachi 705 the procedure recommended by the manufacturer wạs used.

\section{Determination of creatinine}

Two different modifications of the kinetic Jaffé-method (5) were used.

Method I: The alkaline picrate reagent was prepared by mixing equal volumes of $22 \mathrm{mmol} / \mathrm{l} \mathrm{Na}$-picrate and $396 \mathrm{mmol} / \mathrm{l} \mathrm{NaOH}$ buffered with $12.5 \mathrm{mmol} / \mathrm{p}$ phosphate. The reagent was allowed to stabilize for $\mathbf{3 0}$ minutes at room temperature and was then used within 6 hours.

1) Unusual not recommended abbreviations: ASAT, AST, GOT = aspartate aminotransferase ALAT $=$ alanine aminotransferase 
In method II the concentrations of $\mathrm{Na}$-picrate solution and phosphate buffered $\mathrm{NaOH}$ solutions were $34 \mathrm{mmol} / /, 11 \mathrm{mmol} / /$ and $286 \mathrm{mmol} / \mathrm{h}$ respectively.

In both methods the calibration was made by means of three standard solutions containing $0.0,200.0$ and $400.0 \mu \mathrm{mol} / \mathrm{h}$ of creatininc in $30 \mathrm{~g} / \mathrm{l}$ albumin (bovine serum albumin, No. A-8022, Sigma Chemical Company). Aliquots of each standard were stored at $-20^{\circ} \mathrm{C}$ and after thawing were used within one day.

FP-901 procedures two-point: $70 \mu \mathrm{l}$ of serum or standard were dispensed with the nine-channel Finnpipette. In method I the lag time was 60 seconds and the reaction time 120 seconds and in method II 30 seconds and 60 seconds respectively. In method I the reaction proceeded at room temperature $\left(20-25^{\circ} \mathrm{C}\right)$ and in method II at $37^{\circ} \mathrm{C}$.

The analyser measures two absorbance values with the preselected time interval (= reaction time) and calculates a linear standard curve from the measurements of standard solutions by using the method of least squares.

For the Mark I Autoanalyzer, the Technicon standard procedure for the determination of creatinine was adopted.

\section{Specimens}

The control sera used in the long term trial are listed below:

Pathonorm L, batch No. 16, Nyegaard \& Co (P.B. 4220, Oslo 4, Norway)

Pathonorm H, batch No. 18, Nyegaard \& Co

Seronorm, batch No. 155, Nyegaard \& Co

Seronorm Lipid, batch No. 56, Nyegaard \& Co

Precinorm U, lot No. 3-564, Boehringer Mannheim

Precipath U, lot No. 15-512, Boehringer Mannheim

Precilip E.L., lot. No. 4-305, Boehringer Mannheim

Moni-Trol IE, lot. No. LTD-166, Merz and Dade AG (CH-3186 Düdingen), Switzerland).

The control sera were used only on the day of reconstitution. In the case of creatinine the assay was always performed one hour after reconstitution.

Routine patients' sera for the comparison study were obtained from Meilahti Hospital (SF-00290 Helsinki 29, Finland) for the determination of creatinine, and from Mehiläinen Hospital (SF00260 Helsinki 26, Finland) for the determination of aspartate aminotransferase and cholesterol.

All reagents, standard solutions and control sera used in the trials were of the same lot-number.

\section{Calculations}

During the trial each control serum was assayed in triplicate, from which the second and third value were used to calculate the accuracy and precision data. The precision within series was determined by means of two control sera, normal and high, assayed with 18-24 consecutive values on three days of the trial.

For an estimation of carry-over we analysed three successive portions of a serum with a high content of the analysed component followed by three successive portions of one with low content. The first and third value were used according to the procedure described by Broughton et al. (6).

The correlation data were calculated by means of the linear regression analysis (7).

\section{Results and Discussion}

\author{
Review of safety and technical specifica- \\ tions
}

\section{Safety}

The electrical safety was considered satisfactory, since the instrument has been approved for sale as conforming to the regulation of the Electrical Inspectorate. Mechanical hazards were also viewed as insignificant as moving parts were few and movements non-violent in the case of mixer. Microbiological hazards were not apparent in this modular, discrete sample equipment.

\section{Verification of specifications given by the manufac= turer}

The linearity of the absorbance was checked at wave- lengths $340,405,500 \mathrm{~nm}$ using five dilutions of a solution of potassium dichromate at $340 \mathrm{~nm}$, of $4-\mathrm{ni}$ trophenol at $405 \mathrm{~nm}$ and of cobaltous ammonium sulphate $\mathrm{Co}\left(\mathrm{NH}_{4}\right)_{2}\left(\mathrm{SO}_{4}\right)_{2}$ at $500 \mathrm{~nm}$. Each dilution was measured using all nine channels of the instruments of Labs. 2-4. The deviation from linearity was within $\pm 0.5 \%$; however, in one instrument a deviation of $-1 \%$ was recorded at $2.0 \mathrm{~A}$ at wavelengths 405 and $500 \mathrm{~nm}$. From the same set of data the interchannel variation varied between 0.2 and $0.45 \%$ ( $1 \mathrm{CV}$ ). The noise was meassured by 20 consecutive measurements at $10 \mathrm{~s}$ intervals with cuvettes filled with $500 \mu \mathrm{l} \mathrm{H}_{2} \mathrm{O}$ at the three wavelengths. The noise was $\pm 0.001 \mathrm{~A}$ except in one channel in Lab. 4 where it was 0.002 . Drift was followed during $1 \mathrm{~h}$ by measuring the absorbance at three wavelengths at 10 min intervals at the absorbance levels of $0.2-0.4$ and $1.2-1.3 \mathrm{~A}$. The maximal drifts recorded were $\pm 2.3 \% / \mathrm{h}(0.004 \mathrm{~A})$ at the lower range and $-0.8 \% / \mathrm{h}(0.01 \mathrm{~A})$ at the higher range. The authors inspected the records of spectra made by the manufacturer of the interference filters used in the instru= ments obtained with a Varian Cary spectrophotometer and found the specifications to be adequate with regard to wavelength accuracy and half-bandwidth.

The temperature accuracy was measured in one in= strument with the aid of a precalibrated thermistor UVA $33 \mathrm{Jl} 3000$ (Fenwag, Zürich, $\mathrm{CH}$ ) which was immersed into the cuvettes containing $600 \mu_{l} \mathrm{H}_{2} \mathrm{O}$. The temperature was set to 30 or $37^{\circ} \mathrm{C}$, and the temperatures measured after an equilibration period were $29.91^{\circ} \mathrm{C}$ and $36.74{ }^{\circ} \mathrm{C}$, respectively. The difference in temperatures between cuvettes did not exceed $0.20^{\circ} \mathrm{C}$. Temperature fluctuations were within 0.03 and $0.06{ }^{\circ} \mathrm{C}$, respectively. It took 6 and $10 \mathrm{~min}$, respectively, for the temperature to rise from 20- 
$22^{\circ} \mathrm{C}$ to within $0.2^{\circ} \mathrm{C}$ of the temperature. It is thus evident, that the temperature specifications of the manufacturer could not be verified.

In summary, the specifications given by the manufacturer were generally found to be met by the three instruments tested, except for the drift ${ }^{2}$ ) that was occasionally larger, and the temperature accuracy that was found to be less, perhaps due to measurement limitations.

\section{Within-run imprecision}

Three experiments $(n=18-24)$ were performed on three different days by means of two control sera, at normal and high level. Table 1 summarizes the results of the two series with the lowest and highest imprecision within each laboratory. The range of $\mathrm{CV}$

2) According to the manufacturer the drift is specified in non liquid conditions, e.g. with the use of reference filters. for the determination of aspartate aminotransferase was $0.4-2.6 \%$; for cholesterol and creatinine it was $0.4-2.0 \%$ and $1.1-4.7 \%$, respectively.

\section{Between-day imprecision}

Five control sera having low, normal or elevated levels of constituents were analysed on 11-14 days over a period of 3-4 weeks. The results, mean values and coefficients of variation (CV), are shown in table 2 . The CV's were $1.1-4.9 \%$ in the determination of aspartate aminotransferase, and $0.9-5.8 \%$ and $1.3-5.3 \%$ for cholesterol and creatinine, respectively.

\section{Between-laboratory variation}

The aim of multi-centre evaluation is to study the between-laboratory variation using a protocol, designed to minimize sources of variation except those

Tab. 1. Within-run imprecision in the determination of aspartate aminotransferase, cholesterol and creatinine. The lowest $\left(\bar{x}_{\min }\right)$ and the highest $\left(\tilde{\mathbf{x}}_{\max }\right)$ value, the mean $(\overline{\mathbf{x}})$ and the coefficient of variation $(\mathrm{CV} \%)$ are shown. The number of analyses was 18 in $\left.b\right)$ and 24 in a), c) and d). Control 1 and Control 2 were a) Monitrol IE and Seronorm, b) Monitrol IE and Precilip E.L., c) and d) Precinorm $U$ and Precipath $U$.

\begin{tabular}{|c|c|c|c|c|c|c|c|c|c|}
\hline & \multirow[b]{2}{*}{ Laboratory } & \multicolumn{3}{|c|}{ Control I } & \multirow[b]{2}{*}{ CV \% } & \multicolumn{3}{|c|}{ Control 2} & \multirow[b]{2}{*}{$\mathrm{CV} \%$} \\
\hline & & $\overline{\mathbf{x}}$ & $\overline{\mathbf{x}}_{\max }$ & $\overline{\mathbf{x}}_{\text {min }}$ & & $\overline{\mathbf{x}}$ & $\bar{x}_{\max }$ & $\overline{\mathbf{x}}_{\min }$ & \\
\hline \multirow[t]{3}{*}{$\begin{array}{l}\text { a) Aspartate aminotransferase } \\
\text { (U/I) }\end{array}$} & LAB-1 & $\begin{array}{l}52.4 \\
52.2\end{array}$ & $\begin{array}{l}54.0 \\
54.5\end{array}$ & $\begin{array}{l}50.0 \\
50.6\end{array}$ & $\begin{array}{l}2.6 \\
1.8\end{array}$ & $\begin{array}{l}193.0 \\
193.5\end{array}$ & $\begin{array}{l}197.5 \\
194.8\end{array}$ & $\begin{array}{l}189.4 \\
191.2\end{array}$ & $\begin{array}{l}1.0 \\
0.4\end{array}$ \\
\hline & LAB-2 & $\begin{array}{l}54.3 \\
53.3\end{array}$ & $\begin{array}{l}56.3 \\
55.6\end{array}$ & $\begin{array}{l}51.4 \\
51.8\end{array}$ & $\begin{array}{l}2.4 \\
1.9\end{array}$ & $\begin{array}{l}193.7 \\
195.3\end{array}$ & $\begin{array}{l}200.0 \\
200.2\end{array}$ & $\begin{array}{l}187.5 \\
190.2\end{array}$ & $\begin{array}{l}1.7 \\
1.4\end{array}$ \\
\hline & LAB-5 & $\begin{array}{l}54.5 \\
53.6\end{array}$ & $\begin{array}{l}56.8 \\
55.1\end{array}$ & $\begin{array}{l}52.0 \\
50.4\end{array}$ & $\begin{array}{l}2.3 \\
2.0\end{array}$ & $\begin{array}{l}195.8 \\
192.0\end{array}$ & $\begin{array}{l}193.1 \\
190.1\end{array}$ & $\begin{array}{l}197.3 \\
194.1\end{array}$ & $\begin{array}{l}0.6 \\
0.5\end{array}$ \\
\hline \multirow[t]{4}{*}{$\begin{array}{l}\text { b) Cholesterol } \\
(\mathrm{mmol} / \mathrm{l})\end{array}$} & LAB-1 & $\begin{array}{l}3.19 \\
3.23\end{array}$ & $\begin{array}{l}3.27 \\
3.30\end{array}$ & $\begin{array}{l}3.08 \\
3.16\end{array}$ & $\begin{array}{l}1.5 \\
1.1\end{array}$ & $\begin{array}{l}6.86 \\
6.74\end{array}$ & $\begin{array}{l}6.96 \\
6.80\end{array}$ & $\begin{array}{l}6.70 \\
6.67\end{array}$ & $\begin{array}{l}1.0 \\
0.6\end{array}$ \\
\hline & LAB-2 & $\begin{array}{l}3.18 \\
3.15\end{array}$ & $\begin{array}{l}3.38 \\
3.21\end{array}$ & $\begin{array}{l}3.12 \\
3.10\end{array}$ & $\begin{array}{l}2.0 \\
1.0\end{array}$ & $\begin{array}{l}6.72 \\
6.69\end{array}$ & $\begin{array}{l}6.81 \\
6.74\end{array}$ & $\begin{array}{l}6.62 \\
6.65\end{array}$ & $\begin{array}{l}0.8 \\
0.4\end{array}$ \\
\hline & LAB-3 & $\begin{array}{l}3.23 \\
3.35\end{array}$ & $\begin{array}{l}3.34 \\
3.40\end{array}$ & $\begin{array}{l}3.19 \\
3.30\end{array}$ & $\begin{array}{l}1.2 \\
0.7\end{array}$ & $\begin{array}{l}6.73 \\
6.77\end{array}$ & $\begin{array}{l}6.92 \\
6.88\end{array}$ & $\begin{array}{l}6.63 \\
6.67\end{array}$ & $\begin{array}{l}1.1 \\
0.7\end{array}$ \\
\hline & $\mathrm{LAB}=5$ & $\begin{array}{l}3.12 \\
3.13\end{array}$ & $\begin{array}{l}3.17 \\
3.17\end{array}$ & $\begin{array}{l}3.04 \\
3.06\end{array}$ & $\begin{array}{l}1.3 \\
1.0\end{array}$ & $\begin{array}{l}6.64 \\
6.62\end{array}$ & $\begin{array}{l}6.83 \\
6.68\end{array}$ & $\begin{array}{l}6.53 \\
6.55\end{array}$ & $\begin{array}{l}1.1 \\
0.6\end{array}$ \\
\hline \multirow[t]{2}{*}{$\begin{array}{l}\text { c) Creatinine (Method-1) } \\
(\mu \mathrm{mol} / \mathrm{l})\end{array}$} & LAB-3 & $\begin{array}{l}178 \\
178\end{array}$ & $\begin{array}{l}183 \\
180\end{array}$ & $\begin{array}{l}163 \\
173\end{array}$ & $\begin{array}{l}2.4 \\
1.1\end{array}$ & $\begin{array}{l}306 \\
313\end{array}$ & $\begin{array}{l}317 \\
321\end{array}$ & $\begin{array}{l}299 \\
306\end{array}$ & $\begin{array}{l}1.3 \\
1.2\end{array}$ \\
\hline & $\mathrm{LAB}=5$ & $\begin{array}{l}177 \\
178\end{array}$ & $\begin{array}{l}183 \\
182\end{array}$ & $\begin{array}{l}166 \\
175\end{array}$ & $\begin{array}{l}2.3 \\
1.2\end{array}$ & $\begin{array}{l}300 \\
316\end{array}$ & $\begin{array}{l}313 \\
322\end{array}$ & $\begin{array}{l}287 \\
309\end{array}$ & $\begin{array}{l}2.0 \\
1.2\end{array}$ \\
\hline \multirow[t]{3}{*}{$\begin{array}{l}\text { d) Creatinine (Method-II) } \\
(\mu \mathrm{mol} / \mathrm{l})\end{array}$} & LAB-1 & $\begin{array}{l}163 \\
164\end{array}$ & $\begin{array}{l}177 \\
173\end{array}$ & $\begin{array}{l}147 \\
152\end{array}$ & $\begin{array}{l}4.7 \\
3.1\end{array}$ & $\begin{array}{l}292 \\
290\end{array}$ & $\begin{array}{l}306 \\
301\end{array}$ & $\begin{array}{l}274 \\
276\end{array}$ & $\begin{array}{l}3.1 \\
2.2\end{array}$ \\
\hline & LAB-4 & $\begin{array}{l}170 \\
171\end{array}$ & $\begin{array}{l}185 \\
177\end{array}$ & $\begin{array}{l}158 \\
166\end{array}$ & $\begin{array}{l}3.9 \\
1.6\end{array}$ & $\begin{array}{l}310 \\
305\end{array}$ & $\begin{array}{l}324 \\
312\end{array}$ & $\begin{array}{l}287 \\
296\end{array}$ & $\begin{array}{l}3.1 \\
1.7\end{array}$ \\
\hline & LAB-5 & $\begin{array}{l}171 \\
165\end{array}$ & $\begin{array}{l}179 \\
174\end{array}$ & $\begin{array}{l}159 \\
155\end{array}$ & $\begin{array}{l}4.7 \\
3.0\end{array}$ & $\begin{array}{l}291 \\
303\end{array}$ & $\begin{array}{l}307 \\
308\end{array}$ & $\begin{array}{l}279 \\
293\end{array}$ & $\begin{array}{l}3.1 \\
1.3\end{array}$ \\
\hline
\end{tabular}


resulting from the use of different instruments. Table 3 shows the relative differences in the between-day mean value of each laboratory from the mean value of all data. In the case of aspartate aminotransferase the differences were rather small, usually less than $1.5 \%$. However, larger differences obtained with $\mathrm{Pa}$ thonorm $\mathrm{H}$ point to an increased between-vial variation of the lot used, especially since Seronorm, which also has a high value, showed smaller variation. In the determination of cholesterol the differences were mostly below $2 \%$ of the mean of all data. The highest variation was obtained in the determination of creatinine. Probably, this is partly due to other factors than instrumental, since differences in the procedures had not been completely eliminated. However, the variation within-laboratory was of about the same order for creatinine as for other estimations (see tab. 2).

Figures 1,2 and 3 illustrate the comparability of the within-laboratory data, including the between-day imprecision, with the assigned value of control material used. The assigned values provided by manufacturer were, when possible, those given for the type of methodology employed. It is seen that for aspartate aminotransferase all laboratories produced very similar data close to the assigned value. Only the serum with the lowest catalytic concentration gave about $10 \%$ lower results, which represents less than $3 \mathrm{U} / \mathrm{l}$. The estimation of cholesterol gave a very similar picture. All laboratories produced uniform data close to the assigned value. The highest deviation from the assigned value was obtained with Precinorm U. However, the data obtained at the same concentration level with Pathonorm L and Monitrol IE were very close to the assigned value.

In the estimation of creatinine the picture is complicated on the one hand by clear methodological differences and on the other hand by the difficulty in obtaining adequate assigned values. Due to the methodological differences the laboratories had to be divided into two groups, marked with hatched (method I) and open (method II) areas. Method I gave systematically higher results at the concentration level of $100-200 \mu \mathrm{mol} / \mathrm{l}$ than method II, but at higher level the picture is similar for both methods. This is a typical situation in creatinine determination and cannot be attributed to the instrumental factors.

Fig. 1-3. The fraction obtained from the assigned value of the control sera used in the determinations of aspartate aminotransferase, cholesterol, and creatinine (खiii)= method I; $\square=$ method II). The rectangular area represents the between-day-mean value with one standard deviation within each laboratory.

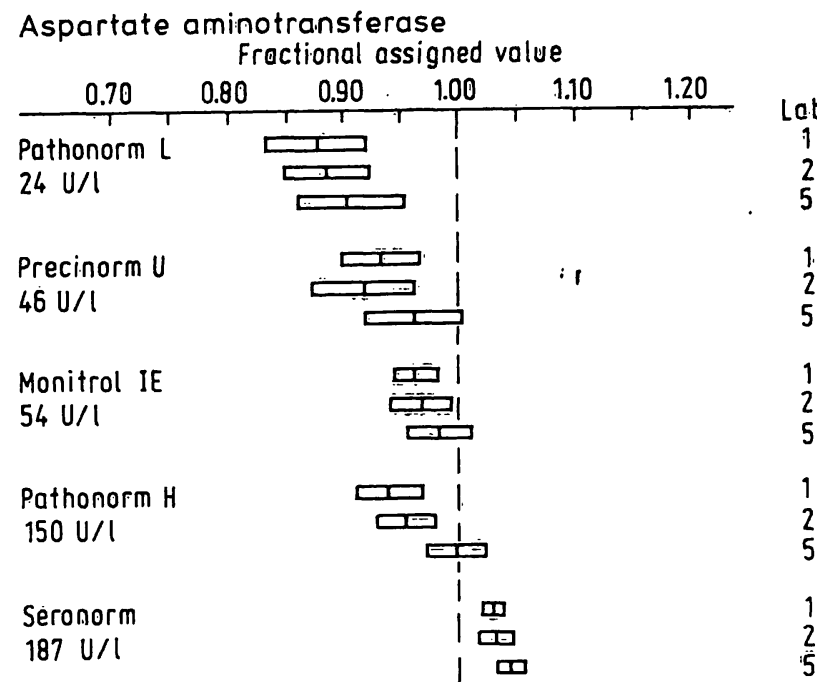

Cholesterol

ractional assigned value

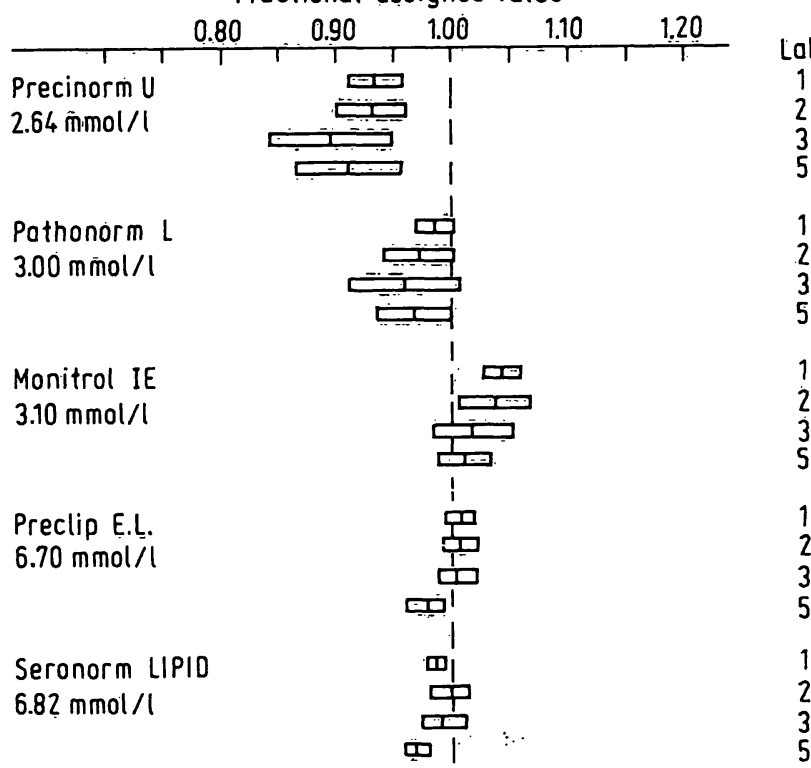

Creatinine

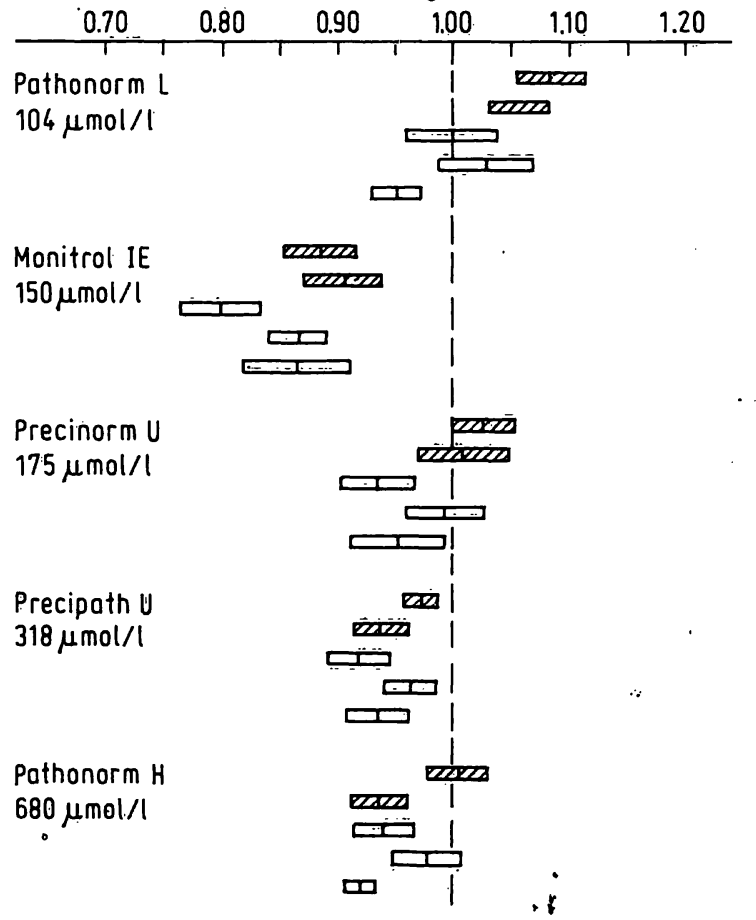


Tab. 2. Between-day imprecision in the determination of aspartate aminotransferase, cholesterol and creatinine, $(n=11-15)$.

\begin{tabular}{|c|c|c|c|c|c|c|c|c|c|}
\hline & Control serum & $\begin{array}{l}\overline{\mathbf{x}} \\
\text { LAB-1 }\end{array}$ & $\mathrm{CV} \%$ & $\begin{array}{l}\overline{\mathbf{x}} \\
\text { LAB-2 }\end{array}$ & CV \% & $\begin{array}{l}\bar{x} \\
\text { LAB-5 }\end{array}$ & $\mathrm{CV} \%$ & $\overline{\mathbf{x}}$ & CV \% \\
\hline \multirow[t]{2}{*}{$\begin{array}{l}\text { a) Aspartate aminotransferase } \\
\text { (U/l) }\end{array}$} & $\begin{array}{l}\text { Pathonorm L } \\
\text { Precinorm U } \\
\text { MoniTrol IE } \\
\text { Pathonorm H } \\
\text { Seronorm }\end{array}$ & $\begin{array}{r}21.1 \\
42.5 \\
52.3 \\
141.2 \\
192.9\end{array}$ & $\begin{array}{l}4.9 \\
3.7 \\
2.0 \\
3.0 \\
1.1\end{array}$ & $\begin{array}{r}21.3 \\
41.8 \\
52.6 \\
143.4 \\
193.2\end{array}$ & $\begin{array}{l}4.2 \\
4.8 \\
2.7 \\
2.8 \\
1.6\end{array}$ & $\begin{array}{r}21.7 \\
43.8 \\
53.5 \\
149.7 \\
195.7\end{array}$ & $\begin{array}{l}4.6 \\
4.5 \\
2.8 \\
2.6 \\
1.2\end{array}$ & & \\
\hline & & LAB-1 & & LAB-2 & & LAB-3 & & LAB-S & \\
\hline $\begin{array}{l}\text { b) Cholesterol } \\
(\mathrm{mmol} / \mathrm{l})\end{array}$ & $\begin{array}{l}\text { Precinorm U } \\
\text { Pathonorm L } \\
\text { MoniTrol IE } \\
\text { Precilip E.L. } \\
\text { Seronorm Lipid }\end{array}$ & $\begin{array}{r}2.47 \\
2.96 \\
3.24 \\
6.76 \\
7.13 \\
\text { LAB-3 }\end{array}$ & $\begin{array}{l}2.5 \\
1.6 \\
1.6 \\
1.2 \\
0.9\end{array}$ & $\begin{array}{r}2.46 \\
2.92 \\
3.22 \\
6.76 \\
7.21 \\
\text { LAB-5 }\end{array}$ & $\begin{array}{l}3.3 \\
3.2 \\
3.0 \\
1.4 \\
1.9\end{array}$ & $\begin{array}{l}2.37 \\
2.88 \\
3.16 \\
6.74 \\
7.17\end{array}$ & $\begin{array}{l}5.8 \\
5.0 \\
3.4 \\
1.6 \\
1.7\end{array}$ & $\begin{array}{l}2.41 \\
2.91 \\
3.14 \\
6.56 \\
7.00\end{array}$ & $\begin{array}{l}4.8 \\
3.4 \\
2.2 \\
1.7 \\
1.1\end{array}$ \\
\hline \multirow[t]{2}{*}{$\begin{array}{l}\text { c) Creatinine (Method I) } \\
\text { ( } \mu \mathrm{mol} / \mathrm{l})\end{array}$} & $\begin{array}{l}\text { Pathonorm L } \\
\text { MoniTrol IE } \\
\text { Precinorm U } \\
\text { Precipath U } \\
\text { Pathonorm H }\end{array}$ & $\begin{array}{l}113 \\
133 \\
180 \\
310 \\
685\end{array}$ & $\begin{array}{l}2.7 \\
3.5 \\
2.8 \\
1.6 \\
2.5\end{array}$ & $\begin{array}{l}110 \\
136 \\
177 \\
299 \\
638\end{array}$ & $\begin{array}{l}2.4 \\
3.8 \\
3.7 \\
2.3 \\
2.5\end{array}$ & & & & \\
\hline & & LAB-1 & & LAB-4 & & LAB-5 & & & \\
\hline $\begin{array}{l}\text { d) Creatinine (Method II) } \\
(\mu \mathrm{mol} / \mathrm{I})\end{array}$ & $\begin{array}{l}\text { Pathonorm L } \\
\text { MoniTrol IE } \\
\text { Precinorm U } \\
\text { Precipath U } \\
\text { Pathonorm H }\end{array}$ & $\begin{array}{l}104 \\
120 \\
164 \\
293 \\
641\end{array}$ & $\begin{array}{l}3.9 \\
4.3 \\
3.4 \\
3.0 \\
2.8\end{array}$ & $\begin{array}{l}107 \\
130 \\
171 \\
307 \\
666\end{array}$ & $\begin{array}{l}4.1 \\
2.8 \\
3.4 \\
2.4 \\
2.9\end{array}$ & $\begin{array}{r}99 \\
130 \\
167 \\
298 \\
627\end{array}$ & $\begin{array}{l}2.2 \\
5.3 \\
4.3 \\
2.9 \\
1.3\end{array}$ & & \\
\hline
\end{tabular}

Tab. 3. Between-laboratory variation in the determination of aspartate aminotransferase, cholesterol and creatinine. $\mathrm{D} \%$ represents the relative difference of the within-laboratory mean value $(\bar{x})$ from the mean of all data $\left(\bar{x}_{101}\right)$.

\begin{tabular}{|c|c|c|c|c|c|c|c|c|c|c|}
\hline$\cdot$ & Control serum & $\begin{array}{l}\text { Mean of } \\
\text { all data }\end{array}$ & $\begin{array}{l}\bar{x} \\
\text { LAB-1 }\end{array}$ & $\mathrm{D} \%$ & $\begin{array}{l}\overline{\mathbf{x}} \\
\text { LAB-2 }\end{array}$ & D \% & $\begin{array}{l}\bar{x} \\
\text { LAB-5 }\end{array}$ & $\mathrm{D} \%$ & $\bar{x}$ & $\mathrm{D} \%$ \\
\hline \multirow[t]{2}{*}{$\begin{array}{l}\text { a) Aspartate aminotransferase } \\
\text { (U/l) }\end{array}$} & $\begin{array}{l}\text { Pathonorm L } \\
\text { Precinorm U } \\
\text { MoniTrol IE } \\
\text { Pathonorm H } \\
\text { Seronorm }\end{array}$ & $\begin{array}{r}21.4 \\
42.7 \\
52.8 \\
144.7 \\
194.0\end{array}$ & $\begin{array}{r}21.1 \\
42.5 \\
52.3 \\
141.2 \\
192.9\end{array}$ & $\begin{array}{l}-1.3 \\
-0.4 \\
-1.0 \\
-2.5 \\
-0.5\end{array}$ & $\begin{array}{r}21.3 \\
41.8 \\
52.6 \\
143.4 \\
193.2\end{array}$ & $\begin{array}{r}-0.1 \\
-2.0 \\
0.3 \\
-0.9 \\
-0.4\end{array}$ & $\begin{array}{r}21.7 \\
43.8 \\
53.5 \\
149.7 \\
195.7\end{array}$ & $\begin{array}{l}1.5 \\
2.5 \\
1.3 \\
3.4 \\
0.9\end{array}$ & & \\
\hline & & & \multicolumn{2}{|l|}{ LAB-1 } & \multicolumn{2}{|l|}{ LAB-2 } & \multicolumn{2}{|l|}{ LAB-3 } & \multicolumn{2}{|c|}{ LAB-5 } \\
\hline \multirow[t]{2}{*}{$\begin{array}{l}\text { b) Cholesterol } \\
(\mathrm{mmol} / \mathrm{l})\end{array}$} & $\begin{array}{l}\text { Precinorm U } \\
\text { Pathonorm L } \\
\text { MoniTrol IE } \\
\text { Precilip E.L. } \\
\text { Seronorm Lipid }\end{array}$ & $\begin{array}{l}2.43 \\
2.92 \\
3.19 \\
6.71 \\
7.13\end{array}$ & $\begin{array}{l}2.47 \\
2.96 \\
3.24 \\
6.76 \\
7.13\end{array}$ & $\begin{array}{l}1.6 \\
1.4 \\
1.5 \\
0.8 \\
0.0\end{array}$ & $\begin{array}{l}2.46 \\
2.92 \\
3.22 \\
6.76 \\
7.21\end{array}$ & $\begin{array}{l}1.4 \\
0.0 \\
1.1 \\
0.8 \\
1.2\end{array}$ & $\begin{array}{l}2.37 \\
2.88 \\
3.16 \\
6.74 \\
7.17\end{array}$ & $\begin{array}{r}-2.3 \\
-1.2 \\
-0.9 \\
0.5 \\
0.5\end{array}$ & $\begin{array}{l}2.41 \\
2.91 \\
3.14 \\
6.56 \\
7.00\end{array}$ & $\begin{array}{l}-0.7 \\
-0.2 \\
-1.7 \\
-2.1 \\
-1.8\end{array}$ \\
\hline & & & $\mathrm{LAB}-3$ & & LAB-5 & & & & & \\
\hline \multirow[t]{2}{*}{$\begin{array}{l}\text { c) Creatinine (Method I) } \\
(\mu \mathrm{mol} / \mathrm{l})\end{array}$} & $\begin{array}{l}\text { Pathonorm L } \\
\text { MoniTrol:IE } \\
\text { Precinorm U } \\
\text { Precipath U } \\
\text { Pathonorm H }\end{array}$ & $\begin{array}{l}112 \\
134 \\
178 \\
305 \\
661\end{array}$ & $\begin{array}{l}113 \\
133 \\
180 \\
310 \\
685\end{array}$ & $\begin{array}{r}0.9 \\
-1.4 \\
0.8 \\
1.7 \\
3.5\end{array}$ & $\begin{array}{l}110 \\
136 \\
177 \\
299 \\
638\end{array}$ & $\begin{array}{r}-0.9 \\
1.4 \\
-0.8 \\
-1.7 \\
-3.5\end{array}$ & & & & \\
\hline & & & LAB-1 & & LAB-4 & & LAB-5 & & & \\
\hline $\begin{array}{l}\text { d) Creatinine (Method II) } \\
\text { ( } \mu \text { mol } / 1)\end{array}$ & $\begin{array}{l}\text { Pathonorm L } \\
\text { MoniTrol IE } \\
\text { Precinorm U } \\
\text { Precipath U } \\
\text { Pathonorm H }\end{array}$ & $\begin{array}{l}103 \\
126 \\
167 \\
299 \\
644\end{array}$ & $\begin{array}{l}104 \\
120 \\
164 \\
293 \\
641\end{array}$ & $\begin{array}{r}0.5 \\
-5.3 \\
-2.1 \\
-2.1 \\
-0.5\end{array}$ & $\begin{array}{l}107 \\
130 \\
171 \\
307 \\
666\end{array}$ & $\begin{array}{l}3.6 \\
2.7 \\
2.2 \\
2.6 \\
3.3\end{array}$ & $\begin{array}{r}99 \\
130 \\
167 \\
298 \\
627\end{array}$ & $\begin{array}{r}-4.1 \\
2.6 \\
0.0 \\
-0.5 \\
-2.8\end{array}$ & & \\
\hline
\end{tabular}


It was rarely possible to find an appropriate assigned value for creatinine. Thus, Pathonorm L carries a socalled "true"-value obtained by the Jaffé method after adsorption on Fuller's earth. Surprisingly, Pathonorm $\mathrm{H}$ from the same manufacturer has an assigned value only for the Autoanalyzer method. The rest of the values are obtained by the kinetic Jaffé method using the Boehringer Mannheim kit. For one of the control sera, Monitrol IE, however, the laboratories consistently obtained lower values. Again, we believe these discrepant results to be due to inadequate establishment of assigned values rather than to the inaccuracy of the analytical procedures in the participating laboratories.

\section{Carry-over}

Since the measuring unit does not produce any carry-over effect, this was determined only for the procedures using the sampler unit. In the determination of aspartate aminotransferase the carry-over varied from 0.1 to $0.6 \%$. The enzyme activities of the control sera used were $187 \mathrm{U} / 1$ (high) and $24 \mathrm{U} / 1$ (low). The assays of cholesterol showed no significant carry-over $(0-0.03 \%)$ with concentrations of $7.2 \mathrm{mmol} / \mathrm{l}$ (high) and $3.0 \mathrm{mmol} / \mathrm{l}$ (low). The difference may be due to the larger sample volume in the former assay, $90 \mu \mathrm{l}$, than in the latter, $10 \mu \mathrm{l}$.

\section{Comparison of the analytical systems}

The procedures adapted to the FP-901 Analyzer produced very similar data to those obtained with the procedures of Hitachi 705 (aspartate aminotransferase and cholesterol) and of the Technicon Autoanalyzer (creatinine).

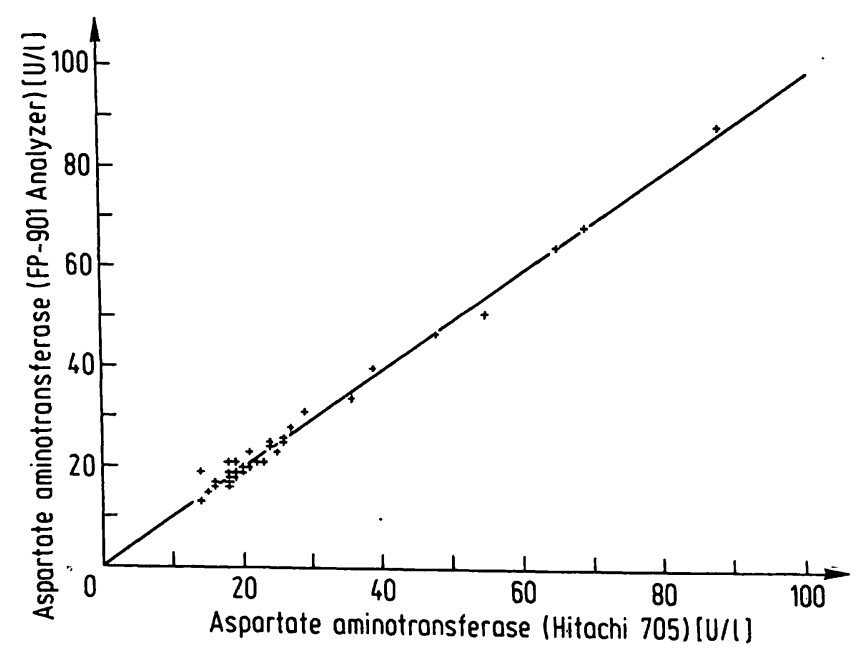

Fig. 4. Aspartate aminotransferase comparison data obtained with Hitachi $705(\bar{x})$ and FP-901 ( $\bar{y})$. From the linear regression analysis: $y=0.974 x+0.529$.
Figures 4-7 and table 4 illustrate the comparison data. Thus, the slope (b) of the regression line is mostly very close to 1 with a little scatter (correlation coefficient 0.99 ). The data also indicate a negligible intercept with the $y$-axis (a) except in the case of modification $I$ in the determination of creatinine. This method produced systematically higher values, which is evident from the data summarized in figure 3 (hatched areas). In this particular system, it was not possible to organize the analytical runs in such a way that the sera could be analysed the same day. Therefore, the sera had to be stored frozen for a few days before the assay with the method I. It was ascertained in one control experiment (not shown) that the storage was not a factor that would contribute to the bias. Nor was it possible to organize the comparison in more than one laboratory per methodology.

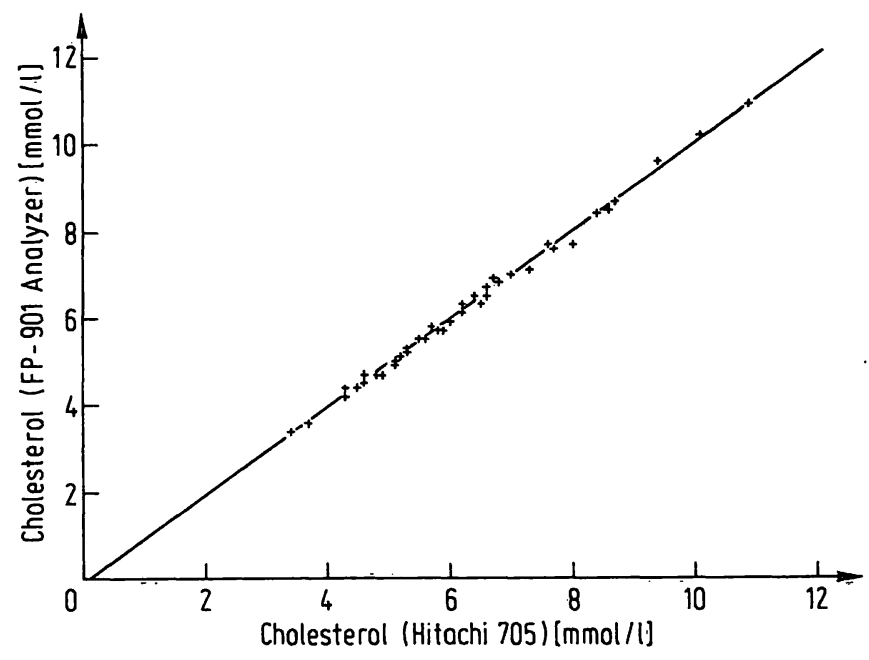

Fig. 5. Cholesterol comparison data obtained with Hitachi 705 $(\bar{x})$ and with FP-901 ( $\bar{y})$. From the linear regression analysis: $\mathrm{y}=1.015 \mathrm{x}-0.136$.

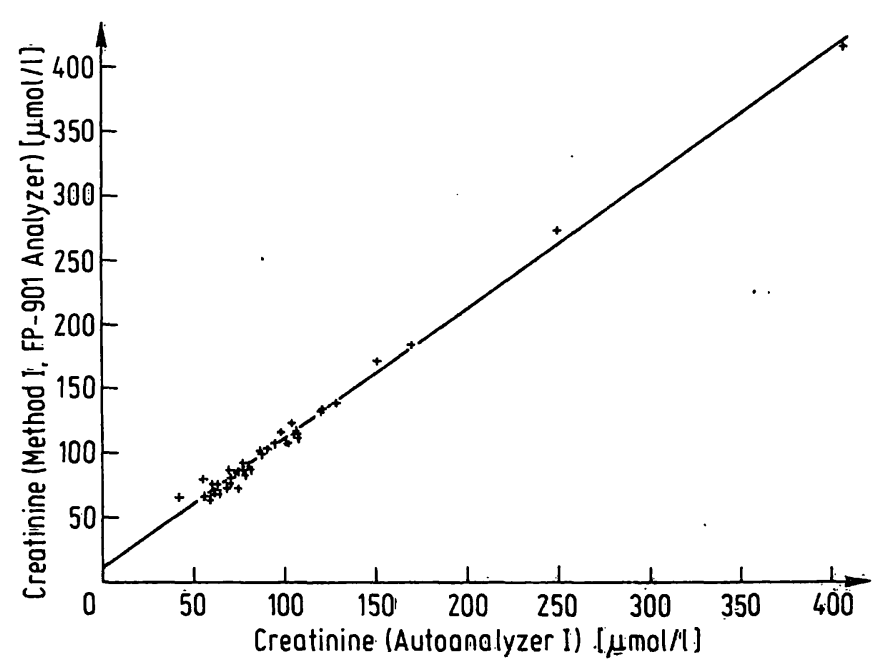

Fig. 6. Creatinine (method I) comparison data obtained with Technicon Autoanalyzer $(\overline{\mathbf{x}})$ and with $\overline{\mathrm{FP}}-901(\overline{\mathrm{y}})$. From the linear regression analysis; $y_{0} \overline{-1.013 x}+10.258$. 
Tab. 4. Comparison of the analytical systems. The number of samples $(n)$, the arithmetic mean valuc of the data obtained with the comparative system $(\bar{x})$ and the system under study $(\bar{y})$, their difference $(\bar{x}-\bar{y})$, and the intercept (a), the slope (b) and the corrclation coefficient $(r)$ obtained by the method of linear regression (7) are given.

\begin{tabular}{lccccccrr}
\hline Method & Lab & $\mathrm{n}$ & $\overline{\mathrm{x}}$ & $\overline{\mathrm{y}}$ & $\overline{\mathrm{x}}-\overline{\mathrm{y}}$ & $\mathrm{a}$ & $\mathrm{b}$ & $\mathrm{r}$ \\
\hline $\begin{array}{l}\text { Aspartate aminotransferase } \\
\text { (U/l) }\end{array}$ & 2 & 43 & 26.7 & 26.5 & 0.2 & 0.53 & 0.97 & 0.995 \\
$\begin{array}{l}\text { Cholesterol } \\
(\mathrm{mmol} / \mathrm{l})\end{array}$ & 1 & 42 & 6.25 & 6.21 & 0.04 & -0.14 & 1.01 & 0.998 \\
$\begin{array}{l}\text { Creatinine (Method I) } \\
(\mu \text { mol/l) }\end{array}$ & 5 & 47 & 96.9 & 108.4 & 11.5 & 10.26 & 1.01 & 0.996 \\
$\begin{array}{l}\text { Creatinine (Method II) } \\
(\mu \text { mol/l) }\end{array}$ & 4 & 85 & 88.5 & 87.9 & 0.6 & 0.44 & 0.99 & 0.990 \\
\hline
\end{tabular}

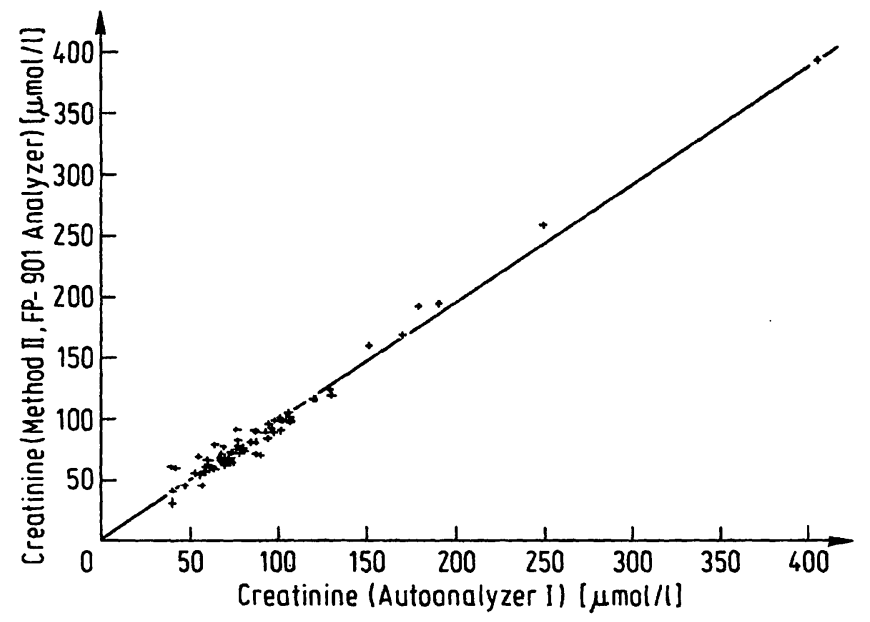

Fig. 7. Crèatinine (method II) comparison data obtained with Technicon Autoanalyżer $(\overline{\mathbf{x}})$ and with FP-901 ( $\bar{y})$. From the linear regression analysis: $y=0.988 x+0.442$.

The influence of the meniscus on the absorbance

The special vertical light pathway of the cuvettes may introduce variables that are absent from photometers in which conventional cuvettes with a fixed light path are used. A priori, the absorbance becomes independent of variations in the volume of added diluents in the cuvette, since it is dependent only on the number of absorbing molecules interacting with the light beam, see l.c. (2), and this parameter remains constant. Thus, it was found that the absorbance was virtually constant with a fixed amount of cobaltous ammonium sulphate in the cuvette when the final volume was varied over a wide range, 150-1000 $\mu \mathrm{l}$ (8), figure 8. In Lab. 3, the absorbance was slightly increased $(0.001 \mathrm{~A})$ only below $200 \mu \mathrm{l}$, while in Lab. 4 there was a gradual increase of absor- bance $(0.01 \mathrm{~A})$ over the range $500-150 \mu \mathrm{l}$. However, samples may contain substances, like protein or detergents, that change the surface tension and thereby increase the curvature of the meniscus. This has two effects, on the one hand the absorbance is no longer independent of the volume (fig. 8), while on the other hand the light path will be decreased. Figure 8 shows that the absorbance is strongly decreased below $300 \mu \mathrm{l}$ and there is a substantial increase in absorbance $(0.035 \mathrm{~A})$ over the range $300-$ $1000 \mu \mathrm{l}$. The decrease of the light path will decrease the absorbance and thereby the slope of the calibration curve. Therefore under these conditions the ap- parent molar absorption coefficient has to be determined (the procedure is given in the manufacturer's manual). Figure 8 also shows that detergents narrow the volume range to $300-1000 \mu l$.

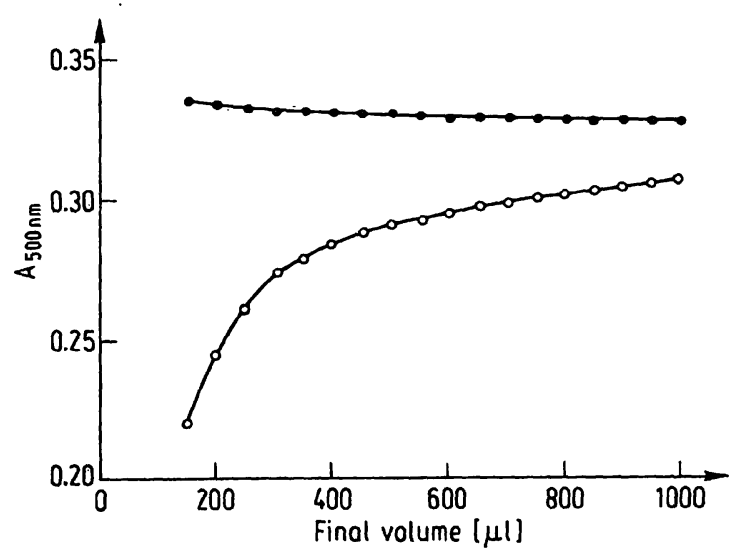

Fig. 8. Influence of solution volume in the cuvette on the absorbance. Absorbance at $500 \mathrm{~nm}$ was measured after addition of increments of $50 \mu \mathrm{l}$ distilled water to a solution of $150 \mu$ l of a solution of $\mathrm{Co}\left(\mathrm{NH}_{4}\right)_{2}\left(\mathrm{SO}_{4}\right)_{2}$ in dilute sulphuric acid.

Open symbols: $1 \mathrm{~g} / \mathrm{I}$ Triton X-100 present. 


\section{Practicability and dependability}

The practicability of an instrument is a matter of subjective opinion. Since the participating laboratories had long experience from using most of the modules of the system and the authors were familiar with its use, the opinions may be of. some interest.

All authors were content with the flexibility and capacity of the system and it was also found to be easy for technicians to learn to use it. In some of the laboratories the instrument was used as a stat-instrument after the daily routine work, which was regarded as a further advantage. The morning maintenance procedures, even after nightly stat-use, were easy and took about 10 minutes. The flexibility was: evident in fast and easy change from one methodology to another. The participants also stressed the feature of storing the calibration data in the memory of the instrument for later use, especially in statwork. A minor comment was the easy changing of the photometer lamp.

On the other hand, a negative comment was the difficulty of sampling sera from tubes of different design. Thus the sampler requires standard sample tubes (three models of the sample tray are available, either for Eppendorf, Technicon or Labsystemstubes).

Due to the vertical light-path the uniformity of the meniscus between the fluid and the air in the cuvette is important. Formation of foam or bubbles could be a problem in the presence of protein or detergents. However, the participants did not view this as a problem, since it is easy to perform pipettings and mixing in such a way that bubbles are not formed even when detergents are present in the reagents.

The dependability of the analytical system was regarded as excellent, and most function failures were in the printer unit of the analyser. For all participants the printer was exchanged once a year and for one twice in 8 months. According to the manufacturer's report the first printer units delivered by the subcontractor did not meet the specifications confirmed.

Another shortcoming was the magnetic contact in the sampler unit, which was too weak to carry full sample trays forward. The magnets were renewed in all samplers.

\section{Speed and capacity}

The capacity of the FP-900 Analyzing system was determined by the participants in connection with the comparison study. In the determination of cholesterol, representing the end-point methodology, a capacity of about 140 analyses per hour was obtained. This includes all steps from sample preparation to recording the results, except the incubation period of 30 minutes. This is about $70 \%$ of the optimal capacity, which can be obtained if sample tubes fitted for the sampler unit are used.

The respective figures for the two-point determination of creatinine (method I) was 120 analyses per hour. This includes sample preparation, manual pipetting steps with 9-channel pipettes, total measuring time of 90 seconds per each batch of nine samples and recording of the data. In enzyme kinetic de= termination, when using a preincubation period of 10 minutes and a total measuring time of 150 seconds per batch of nine samples, the capacity obtained was about 100 analyses/hour. Again, this is about $70 \%$ of the optimal capacity due to the additional step required for dividing the samples into tubes fitted for the sampler unit.

\section{Cost analysis}

During this study the consumption of reagents, standards and disposables was registered. Therefore, it was possible to calculate the cost per test based on practical experience and to compare this value with the value derived from the theoretical calculations.

In the determination of aspartate aminotransferase, requiring a total reagent volume of $660 \mu \mathrm{l}$ per test, the cost per one test was found to be 0.15 USD, $50 \%$ of that originating from reagents and the other $50 \%$ from disposables. This figure is about $12 \%$ higher than the theoretical one.

In the determination of cholesterol the cost was found to be about 0.17 USD per test and 0.22 USD per one sample. From these values more than half $(60 \%)$ comes from reagents $(500 \mu \mathrm{l} /$ test $)$ and standards and the rest from disposables. Again, this is about $13 \%$ higher than the theoretical one.

Since the creatinine procedures were not based on any commercial reagent kit, the cost was only 0.12 USD per one test and 0.14 USD per one sample, from which the share of reagents $(700 \mu \mathrm{l} /$ test $)$ is less than $5 \%$. Of course, to this should be added cost of the working time required for reagent preparation.

The cost including technician salary, instrument purchase and maintenance cost, are more difficult to calculate due to the lack of an agreed procedure for calculations. Other difficulties arise from fluctuations in currency exchange rates and effect of differences in local taxation and sales practices. 
Experiences from applying the ECCLS 1 st draft

"Standard for Instrument Testing"

The draft became available to us at the stage when comments on it were solicited. The virtues and shortcomings of such a draft are best recognized by firsthand experience from applying it to actual testing of an instrument. The concept of using multi-centre trials with close cooperation among the evaluators themselves and with the instrument manufacturer was deemed approvable. Indeed, one instrument in the manufacturer's laboratory was included. Since this instrument fared no better or worse than the rest of the instruments it was included in the report. A multi-centre trial is to be preferred as giving a more representative and objective picture of the performance than testing a single instrument. The cooperation with the manufacturer made the performance more smooth since various services were provided: transport of specimens, purchase of control sera and reagents, typing etc. At the same time no bias one way or the other was allowed to develop, and both the manufacturer and the participants could check that the instruments were in proper condition and were giving representative data. The manufacturer had the benefit of introducing a newly developed sampler in the evaluation.

In the Draft, Part I is devoted to testing the safety and the specifications. We did not devote much time to the safety, since it was considered to be adequate. Some minor deviation from specifications were found, however. Part II describes the "clinical" testing which was the most important section. The familiarisation period was necessary only for the new sampler. The selected typical methodologies were easily performed and the Draft is useful in pointing out the relevant factors involved. The short term trial proved to be very useful indeed. Differences in minor details that had not been apparent in the initial planning were found to require attention. Though the participants were very cooperative, they were not willing to change their routine methods in all instances, but agreed to make extra runs for this purpose. Nevertheless, it was not possible to carry out all methodologies in all laboratories, and in the case of creatinine, differences in protocol persisted. For the most part we achieved the objective of minimizing influences on the variability, other than those emanating from instrumental factors.

The Draft stresses that criteria for the acceptability in regard to imprecision and deviation from assigned values are fixed before the short-term trial. This proved to be easy for the imprecision in which case the general recommendations of the Finnish national quality control scheme were followed. It was, however, not possible with regard to the deviation from assigned values, due to the great variability in the establishment of assigned values by manufacturers of control materials. This, however, was not a cause for concern; since there did not appear to be any obvious differences between the laboratories. The rare instances of deviation from assigned values showed only moderate deviation, which most likely are due to inadequate assigned values. The long-term trial was carried through without any difficulties, using the protocol of the Draft. However, it was not always possible to organize the comparison of analytical systems in the recommended way with analyses performed by the two systems the same day. Nor was it possible within the busy time schedules of routine laboratories to separate for further investigation any sera suspected of causing interference.

The Draft Document as a whole forms a sound basis for instrument evaluation. Some recommendations in it (see above) were too impractical to be followed stringently.

\section{References}

1. Suovaniemi, O. (1976) Performance and properties of the Finnpipette Analyzer System, Prọceedings of the Second National Meeting on Biophysical and Biotechnology in Finland (A. L. Kairento, E. Ruihịmäki \& P. Tarkka, Eds.), pp. $183-187$.

2. Suovaniemi, O. \& Jä̀nefelt, J. (1982) International Laboratory, Ap̈ril 1982, pp. 48-60.

3. 1st Draft Standard for Instrument Testing, June 1981, European Committee for Clinical Laboratory Standards Document Vol. 1, No. 3.

4. Scandinaviän Standardizations of Enzyme Determination (1974) Scand. J. Clin. Lab. Invest. 33, 287-306.

5. Bartels, H., Böhmer, M. \& Heierli, C. (1972) Clin. Chim. Acta 37, 193-197.

6. Broughton, P. M. G., Gowenlock, A. H., McGormack, J. J. \& Neill, D. W. (1974) Ann. Clin. Biochem. 11, 207-218.

7. Westgaard, J. O. \& Hunt, M. R. (1973) Clin. Chem. 19, 49-57.

8. Saris, N.-E., Kansanen, M., Huurrekorpi, L. \& Närvänen, S. (1978) Abstracts of the International Congress of Clinical Chemistry, Mexico City, p. 114.

Nils-Erik Saris, Prof.

Department of Medical Chemistry

University of Helsinki

Siltavuorenpenger 10

SF-00170 Helsinki 17 
